\title{
Home hemodialysis: a comprehensive review of patient-centered and economic considerations
}

This article was published in the following Dove Press journal:

ClinicoEconomics and Outcomes Research

16 February 2017

Number of times this article has been viewed

\author{
Rachael C Walker ${ }^{1,2}$ \\ Kirsten Howard' \\ Rachael L Morton ${ }^{3}$ \\ 'School of Public Health, Sydney \\ Medical School, University of Sydney, \\ Sydney, Australia; ${ }^{2}$ Hawke's Bay \\ District Health Board, Hastings, \\ New Zealand; ${ }^{3}$ NHMRC Clinical \\ Trials Centre, Sydney Medical School, \\ University of Sydney, Sydney, Australia
}

Correspondence: Rachael L Morton NHMRC Clinical Trials Centre, Sydney Medical School, University of Sydney, Locked Bag 77, Camperdown NSW, 2050, Australia

Email rachael.morton@ctc.usyd.edu.au

\begin{abstract}
Internationally, the number of patients requiring treatment for end-stage kidney disease (ESKD) continues to increase, placing substantial burden on health systems and patients. Home hemodialysis (HD) has fluctuated in its popularity, and the rates of home HD vary considerably between and within countries although there is evidence suggesting a number of clinical, survival, economic, and quality of life (QoL) advantages associated with this treatment. International guidelines encourage shared decision making between patients and clinicians for the type of dialysis, with an emphasis on a treatment that aligned to the patients' lifestyle. This is a comprehensive literature review of patient-centered and economic impacts of home HD with the studies published between January 2000 and July 2016. Data from the primary studies representing both efficiency and equity of home HD were presented as a narrative synthesis under the following topics: advantages to patients, barriers to patients, economic factors influencing patients, cost-effectiveness of home HD, and inequities in home HD delivery. There were a number of advantages for patients on home HD including improved survival and QoL and flexibility and potential for employment, compared to hospital HD. Similarly, there were several barriers to patients preferring or maintaining home HD, and the strategies to overcome these barriers were frequently reported. Good evidence reported that indigenous, low-income, and other socially disadvantaged individuals had reduced access to home HD compared to other forms of dialysis and that this situation compounds already-poor health outcomes on renal replacement therapy. Government policies that minimize barriers to home HD include reimbursement for dialysis-related out-of-pocket costs and employment-retention interventions for home HD patients and their family members. This review argues that home HD is a cost-effective treatment, and increasing the proportion of patients on this form of dialysis compared to hospital HD will result in a more equitable distribution of good health outcomes for individuals with ESKD. Keywords: hemodialysis, home haemodialysis, economic considerations, end stage kidney disease, patients, quality of life
\end{abstract}

\section{Background}

Home hemodialysis (HD) was developed in the 1960s in the USA and the UK, and by the early 1970 s, $59 \%$ of patients on dialysis in the UK and $32 \%$ of patients in the USA received dialysis at home, mostly overnight hemodiaysis. ${ }^{1}$ At this time, hospital dialysis was accessible to only a limited number of patients with end-stage kidney disease (ESKD). Home HD offered a solution that allowed more people to dialyze within the limited health system budget. ${ }^{2}$ Over the last 50 years, the worldwide incidence of ESKD has exploded, and currently, dialysis accounts for a substantial burden on many health systems. ${ }^{3,4}$ In 2010, the number of patients on dialysis was 2.050 million, with recent modeling predicting that this number will be more than double between 
2010 and 2030. ${ }^{5}$ Despite this exponential growth in the total number of dialysis patients, the proportion of those on home HD since the 1970s has diminished and remains surprisingly low, whereas the numbers of patients preferring hospital and satellite dialysis have substantially increased. The low utilization of home HD is a lost opportunity both to decrease health system costs and to improve quality-adjusted survival.

International rates of home HD vary considerably; countries with a strong home HD "culture" such as New Zealand and Australia sustain $18 \%$ and $9 \%$ of all dialysis patients on home HD, respectively. This compares to 3-6\% in Canada and western Europe with other countries having $\leq 3 \% .{ }^{6}$ One exception is the UK, where there is a steady growth in the numbers of patients on home HD over the last 10 years, ${ }^{7}$ since the National Institute of Health and Care Excellence implemented a 15\% target for home HD and recommended that the most appropriate modality was one that aligned to the patients' lifestyle and personal circumstances, alongside their clinical requirements. ${ }^{8}$

Home HD can be performed independently by the patient or with the assistance of a caregiver, allowing a more flexible and convenient option compared to hospital or satellite (henceforth referred to as facility) HD. Home HD also offers the ability to increase the hours and frequency of treatment. Recent data, including those from randomized controlled trials, suggest that the benefits of more frequent dialysis are similar to kidney transplantation, including greater solute clearance, better volume control potentially reducing left ventricular hypertrophy, improved nutrition, and improved quality of life (QoL). ${ }^{9-11}$ Conventional home HD (three times per week, 4-5 h per treatment) is also associated with a number of benefits compared to facility HD including a lower risk of death, improved blood pressure control, higher QoL, and a greater chance of maintaining employment. ${ }^{12-15}$ In contrast, facility dialysis is more restrictive, and hours are generally inflexible with a maximum dialysis duration of $3.5-5 \mathrm{~h}$ to accommodate multiple dialysis sessions per machine. Notwithstanding, facility dialysis is substantially more expensive, predominantly due to nursing and technical staff and facility overheads. However, there are reported disadvantages of home HD, including the burden it can impose on caregivers and family members. ${ }^{16,17}$ Concerns also exist regarding the complexity of home $\mathrm{HD}^{18}$ and patient safety while performing unsupervised HD at home. ${ }^{18-20}$

Home HD offers numerous patient-centered and economic benefits; however, a number of barriers to uptake and maintenance of this treatment also exist; these are addressed in the following sections with a focus on contemporary home HD modalities, including extended hours per week with "short daily" or "nocturnal" home HD.

\section{Methods}

This is a comprehensive literature review of patient-centered and economic impacts (including both efficiency and equity considerations) of home HD. The databases MEDLINE, PreMEDLINE (Ovid), National Health Service Economic Evaluation Database, Cochrane Library, EMBASE, CINAHL, Google Scholar, EconLit, and Scopus were searched by using a comprehensive list of Medical Subject Headings terms and text words for HD (haemodialysis), home HD, nocturnal, daily, quotidian, patient experiences, qualitative, cost-effectiveness, cost utility, economic evaluation, life years, quality-adjusted life years, and costs. The search was limited to publications from January 1, 2000, to July 30, 2016, and manuscripts written in English. All the titles and abstracts were manually screened to identify relevant studies. Review studies were screened for references of further primary studies.

The titles and abstracts were screened by RCW, and full papers considered potentially relevant were retrieved. The data were extracted by RCW and RLM. Among papers considering all forms of dialysis, this review included only the papers containing information relevant to home HD. Studies or reports were included if they explored either patient-centered or economic perspectives of patients on home HD. Studies on clinical, survival, or clinician perspectives only were excluded. In this review, the data from the primary studies were presented in a narrative synthesis of findings under the following home HD topics: advantages to patients, barriers to patients, economic factors influencing patients, cost-effectiveness, and inequities in home HD delivery. Table 1 summarizes the barriers to home HD and potential solutions to overcome these barriers.

\section{Results}

The search resulted in 102 articles, and after titles and abstracts were assessed for relevance and the exclusion criteria applied, 61 studies were included in this review. Figure 1 describes the search process. The study types were divided into two broad categories: patient-centered considerations, which included studies related to the advantages of and barriers to home HD, and economic considerations. Table S1 lists the included study titles.

\section{Patient-centered considerations}

\section{Advantages for patients}

Contemporary home HD has been shown to be associated with substantial clinical benefits, not least survival rates with nocturnal home HD being comparable to rates observed 
Table I Home HD barriers and potential solutions

\begin{tabular}{|c|c|}
\hline Barriers & Potential solutions \\
\hline Lack of exposure, visibility, and education regarding home HD & $\begin{array}{l}\text { Units adopt formal predialysis education with nonbias information regarding all } \\
\text { treatment options }\end{array}$ \\
\hline \multirow[t]{2}{*}{ Preconception that home HD is "too difficult and complex" } & Training for clinical staff to increase confidence in home HD \\
\hline & Utilization and further development of simpler home HD training machines \\
\hline Lack of patient confidence to perform home HD & Peer support from established home HD patients \\
\hline Fears of vulnerability and isolation from medical support & Strong clinical recommendation for home HD \\
\hline Unexpected problems at early stage of home HD & Increased support when patient transitioning home \\
\hline \multirow[t]{2}{*}{ Fear of self-cannulation } & Technological support for patient at home \\
\hline & Community house models of care \\
\hline \multirow[t]{3}{*}{ Caregiver burden } & Encouraging home HD independence with enhanced support \\
\hline & Paid models of support - family members or support staff \\
\hline & Inclusion of family members in education and training \\
\hline \multirow[t]{3}{*}{ Increased cost of home HD to patient } & Transparent information regarding expected costs \\
\hline & Reimbursement for out-of-pocket costs \\
\hline & Community houses \\
\hline Increased travel expenses & $\begin{array}{l}\text { Units provide flexible and individualized training programs (after hours } / 5 \text { day } \\
\text { week/training in home) }\end{array}$ \\
\hline Extended training duration & Exploration of return and training work policy \\
\hline \multirow[t]{2}{*}{ Housing problems (storage and water quality) } & Developments in technology and home HD machines \\
\hline & Independent community houses \\
\hline \multirow[t]{4}{*}{ Socioeconomic disadvantage } & Reimbursement for out-of-pocket, transport, and setup costs \\
\hline & Independent community houses \\
\hline & Increased support and peer education for minority and indigenous groups \\
\hline & Government policy and incentive programs \\
\hline
\end{tabular}

Abbreviation: HD, hemodialysis.

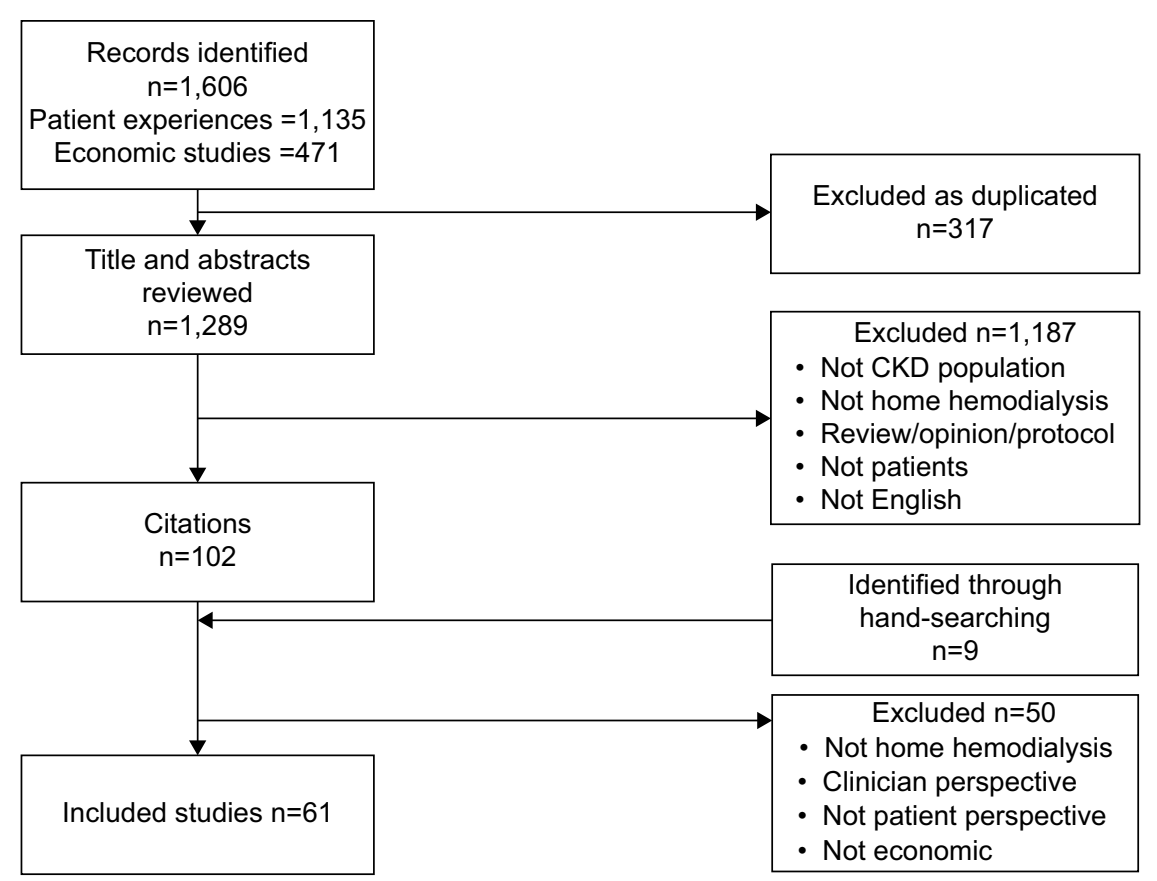

Figure I PRISMA flow chart of included studies.

Abbreviation: CKD, chronic kidney disease.

in deceased donor kidney transplant recipients. ${ }^{21}$ Of equal importance, patient-centered research has identified that $\mathrm{QoL}$ factors such as daytime freedom and flexibility, employment, fatigue, caregiver burden, and ability to maintain "normal activities" are of great concern to patients. ${ }^{22-28} \mathrm{~A}$ recent qualitative systematic review of patient and caregiver's perspectives found that home HD offered the opportunity to thrive; improved freedom, flexibility, and well-being; and 
strengthened family relationships. ${ }^{22}$ Patients valued their ability to work and the sense of self-value that employment provided. ${ }^{23,29}$

Unemployment in working-age people is known to be associated with high rates of anxiety, depression, and low self-esteem. ${ }^{30}$ Considering that nearly half of the dialysis population is of working age, employment retention is extremely important. The scheduling restrictions of facility dialysis reduce employment opportunities for patients; a study showed that only $43 \%$ of the patients maintained the same level of employment after 6 months..$^{29}$ In contrast, contemporary home $\mathrm{HD}$ allows for greater treatment schedule flexibility and therefore more chance of sustained employment. ${ }^{31}$ Employment, both paid and unpaid, has productivity benefits for society as well as financial stability for individuals and their families. Future economic evaluations of dialysis modalities should include these broader societal benefits that fall beyond direct benefits to health systems.

Home HD also enables patients to maintain social relationships, avoid relocation to a major city for facility dialysis, and maintain cultural involvement, which is particularly important for people living in rural areas and for indigenous populations. ${ }^{23}$ One study reported that patients on home HD were reluctant to undergo a kidney transplant (considered the gold standard treatment in renal replacement therapy [RRT]) as they believed that there was little additional benefit from their current health status and the potential risks of transplantation were not worth the risk. ${ }^{32}$

\section{Patient barriers to home HD}

Patients new to home HD initially described lacking confidence about their own ability to master home HD and fears about being isolated from medical support; their vulnerability if a medical catastrophe were to occur; and anxiety about specific aspects of home HD, particularly inserting needles. ${ }^{22}$ Patients also described home HD as being portrayed by educators and clinicians as a complex treatment that was difficult to learn and therefore might be "beyond their capabilities," resulting in patients doubting their own ability to perform home HD safely. ${ }^{23}$ Hanson et al's ${ }^{33}$ mixed methods study of 20 Australian patients undergoing training for home HD identified that patients experienced unexpected problems throughout the first few weeks of home HD, which caused doubt in their ability to dialyze independently. Similarly, Young et al described the first 3 months of independent home HD as a critical period in determining the success of long-term home HD. ${ }^{34}$ In a previous study, patients established on home HD acknowledged these early fears; however, they also spoke of their trepidation being alleviated over time as their confidence increased. Patients cited peer support and clinician recommendation of home HD as a superior treatment for them and the doctors' trust in the patients' ability to perform this treatment independently as an encouragement of this treatment choice. ${ }^{23}$

Other barriers to patients in taking up home HD include a lack of knowledge, exposure, visibility, and perceived complexity of this modality. ${ }^{19,23}$ Lack of effective patient education regarding all the dialysis modalities may influence this, as effective predialysis education has been shown to significantly increase patient choice of a home modality. ${ }^{35-37}$ This has been acknowledged in a previous work based in the USA where up to $88 \%$ of patients in 2005 were not aware of home HD as an option. ${ }^{36}$

Although New Zealand and Australia have relatively high rates of home HD, there is large regional variability in these rates, suggesting further potential to increase home HD overall. Both these countries and others such as Canada have the advantage of supporting patients to dialyze without the requirement of a caregiver or adult to be present during each treatment session. In two previous qualitative studies, patients considered the burden of home HD on their family, but also acknowledged that the inclusion of family members in education and training would help to alleviate some of these concerns. ${ }^{23,33}$

Home HD was traditionally considered appropriate for "young and well" patients; however, more recently, countries such as the UK have found that patients in their 70s and $80 \mathrm{~s}$ are successfully performing home HD independently and may benefit from this modality. A multinational retrospective cohort study of 79 patients aged $\geq 65$ years confirmed feasibility of home HD in this patient group. Although this study did not measure patient-reported outcome measures (PROMs), it may be assumed that, given the patient-centered benefits from other studies, this group could also benefit from home HD. However, the authors of this study did highlight the potential for long training duration and increased caregiver burden, with $>50 \%$ of the patient cohort requiring some home assistance. ${ }^{38}$ More recently, Australasian countries have developed novel ways of increasing their home HD rates. In southern New Zealand, assisted home HD programs have ensured that some elderly are able to remain on home HD with the trained support staff (generally enrolled nurses). Assisted home HD has also shown promising results in a recent pilot study in Canada, and plans are under way to expand the number of participants to a larger cohort and to explore the cost-effectiveness of the program. ${ }^{39}$ The adoption 
of community dialysis houses has also been a successful initiative in New Zealand to provide home HD for patients to independently dialyze in a home environment. These patients would not otherwise be able to dialyze in their own home, because of factors such as overcrowding, lack of storage, concerns of patient safety, or reluctance to "medicalize" the home environment. ${ }^{40}$ This initiative was highly valued by Australian patients already dialyzing in the hospital setting. ${ }^{41}$ Using this concept in other countries may help to address some of the identified socioeconomic and social isolation barriers to home HD previously reported by patients. For the centers planning to establish home HD programs, initial investment and commitment are required due to the requirements such as extensive nurse education, patient training, and infrastructure support. ${ }^{42}$

\section{Economic considerations}

Hanson et al conducted a qualitative study ${ }^{33}$ reporting that patients undergoing training for home HD often had to sacrifice their annual leave to accommodate the longer training duration of home HD and as such incurred high out-of-pocket expenses that drained their financial reserves. Despite this, patients weighed these costs against their opportunity for employment and improved lifestyle and livelihood on home HD. Patients felt that the out-of-pocket costs were unfair and that available reimbursements were inadequate. These findings are similar to the economic factors influencing dialysis decision making that was identified in qualitative interviews with predialysis and dialysis patients in New Zealand ${ }^{43}$ In this study, patients considered their potential financial losses when choosing a dialysis modality, particularly in relation to maintaining or resuming employment. ${ }^{24}$ In the present study, both patients and caregivers believed that it was unfair and inequitable that those on home dialysis personally subsidized the cost of their treatment, whereas facility dialysis patients did not incur many additional out-of-pocket costs. It was also observed that socioeconomic disadvantage was a barrier to home dialysis due to multiple factors including unsuitable housing, the lack of home ownership, and not being able to afford the required out-of-pocket costs. In an Australian study of nephrologists, lack of patient reimbursement for out-ofpocket costs was also a barrier to clinicians in promoting home dialysis. ${ }^{44}$

Financial barriers to home HD are a hurdle that may easily be overcome with a direct policy change. ${ }^{24} \mathrm{~A}$ national survey of home HD programs in Canada identified that although the majority of programs partially reimbursed patients' expenses for minor plumbing and electrical renovations (88\%), this was more commonly a one-off cost and less than a third of programs reimbursed for ongoing out-of-pocket utility costs $(29 \%)$. This survey also identified that over half of the home HD programs required a care partner at home with them when they dialyzed, the majority of whom were unpaid family members or living companions, raising the issue of equity for the patients without a care partner. ${ }^{45}$

Access to home HD training for patients who are living rural areas is often a barrier, particularly if there is a waiting or extended training duration, meaning that patients need to temporarily relocate during training. This relocation can significantly impact on the patient and their family, including financial burden and cultural and social dislocation from their community.

\section{Cost-effectiveness of home HD}

Previous studies, including a recent systematic review, have suggested home HD to be less expensive than facility HD. ${ }^{46}$ One review of contemporary home HD practice, including nocturnal and daily regimens, reported generally equivalent costs or cost-effectiveness compared to conventional facility $\mathrm{HD} .{ }^{47}$ Both reviews concluded that, in general, home HD was associated with lower costs and better outcomes compared with facility hemodialysis. Even when highdose HD was available in hospitals, a modeled cost-utility analysis from the UK reported this modality would not be cost-effective, whereas home HD was considered "dominant" with both lower total costs and higher health outcomes than conventional HD. ${ }^{48}$ Although the studies included in this reviews showed home HD to be cost-effective, only one study included patients' out-of-pocket expenses, training time, and productivity losses, ${ }^{49}$ a topic that requires further exploration in order to assess the full impact on the patient and their family and society.

In countries such as the USA, currently, there lacks concordance between the costs of training a patient for home $\mathrm{HD}$ and the Medicare reimbursement. ${ }^{50}$ Internationally, reimbursements for hospital HD are generally higher with the exception of the USA and UK; both of whom provide a flat rate regardless of dialysis location, a factor that may influence the low uptake of home HD. In contrast, the Netherlands has home HD reimbursed at a higher amount if the patient needs a nurse or a nurse assistant, but without an assistant, it is reimbursed lower than hospital HD. ${ }^{51}$ Reimbursement strategies have proven favorable for increasing the rates of peritoneal dialysis (PD) use ${ }^{52}$ as have incentive programs,${ }^{53}$ and these may have similar impact on the rates of home HD. A recent UK study comparing home dialysis rates of seven 
hospitals across the West Midlands with the rest of England demonstrated that the use of dialysis modality targets with financial penalties (ie, pay-for-performance) to increase home dialysis was successful, increasing the average uptake by $23 \%$ compared to a slight decrease in rates across the rest of England for a group of patients with complex medical problems. The qualitative component of this study also highlighted two neglected areas needed to increase home dialysis uptake in patients with complex medical needs: identifying individualized patient education and the ability to provide an ongoing emotional support. ${ }^{54}$

More recently, PD-First programs have proved successful in countries such as Hong Kong and Thailand, who have instituted policy on PD through the creation of incentives for provider and patient use, including full reimbursement of PD and restricted reimbursement of HD for patients with a contraindication to PD. ${ }^{55}$ Although it is a valid and costeffective approach in the short term, the shorter technique survival of PD over time ${ }^{15,56}$ may result in these countries facing another challenge in the future years as their dialysis population transitions from $\mathrm{PD}$ to $\mathrm{HD}$. The direct transition from PD to home HD may help to address this issue. ${ }^{57,58}$

\section{Inequities in home HD delivery}

The high cost of dialysis has created inequitable access of not only home HD, but also RRT across the world, described recently as a "RRT gap." Liyanage et $\mathrm{al}^{5}$ estimated that although an estimated 2.6 million people worldwide were treated for ESKD in 2010, up to three times that number may have died from ESKD due to limited access or financial barriers to dialysis. Internationally, it is recognized that a country's gross domestic product and health care expenditure predict the prevalence of dialysis treatment. ${ }^{59}$ For low-income countries or those vastly dispersed, home HD may offer numerous additional benefits to improve the accessibility of dialysis. The considerable variability in international practices indicates many potential areas for improvement in the uptake of home HD. The number of patients on home HD in countries such as New Zealand indicates that, with greater exposure and availability, increase in the number of patients preferring home HD is achievable in other countries. From an epidemiological perspective, it is arguable that contemporary home HD, which is at least cost-neutral, if not cost-effective compared to facility dialysis, and has significant health gains and QoL improvements, is worth closer consideration.

However, inequities do not just exist between countries in access to home HD. Within countries with high rates of home HD (New Zealand, Australia, and Canada), minority populations and indigenous groups have significantly lower rates of home HD for reasons that remain poorly understood. ${ }^{60,61}$ In the USA, Hispanic patients are 37\% less likely to receive home HD, and black patients are $17 \%$ less likely to receive home HD than white patients. ${ }^{62}$ Recent data also suggest that countries with lower average incomes and more minority groups have a lower number of facilities offering home HD. ${ }^{50}$ These low rates may also be compounded by the existing social gradient in predialysis patients' access to health care, particularly for those without health insurance or home ownership, as this group is known to be significantly less likely to access specialist nephrology and cardiovascular health services. ${ }^{63}$

In 2016, the National Kidney Foundation's presidential address acknowledged that there is no method to accurately predict the "right" rates of home HD without understanding the choices of fully informed, nonbiased, and educated patients who are not influenced by the economics of their health system and, therefore, the availability of treatments. ${ }^{64}$ However, it was known that faced with their own decision of modality, nearly half of the nephrologists would choose home HD if transplantation was not an option, ${ }^{65}$ and therefore, it can be assumed from this that home HD represents an appropriate "target," given nephrologists are a well-informed and educated group.

\section{Conclusion}

Although a number of barriers to increased uptake of home HD have been defined in this review, none are insurmountable. They require changes in renal unit practice and government policy. The evidence in this review argues that home HD is a patient-centered and cost-effective treatment and that increasing home HD uptake could assist in reducing inequities that currently exist internationally and locally. It was acknowledged, however, that the changes required would need financial investment and a long-term planning approach, as the benefits may not be realized in the short term.

This review emphasized the need for nephrology to better meet patient priorities. The alternative for "one size fits all" approach should be found, and the delivery of home HD training and care should be modified to better support the patient and their family. Promisingly, a recent systematic review and survey of renal registries reported the need for registries to routinely collect PROMs and patient experiences. ${ }^{66}$ This systematic approach will help clinicians and policy-makers to understand the patient-centered benefits and downsides of all dialysis modalities and ensure that RRT is provided equitably and in a manner that is aligned with patient's preferences. 
Although previous economic studies have predominantly focused on the benefits to the health care system, patientcentered, economic considerations also impact on patient treatment choice and have a wider societal impact that must be explored. Given the clinical, patient, and economic benefits of contemporary home HD, it is difficult to understand why the proportions among high-income countries where home HD training and infrastructure are available remain so low. Government policy needs to address the areas of disadvantage and inequity that face minority and indigenous groups and those with low incomes and explore ways to support reimbursement, incentives, and employment for patients and their family members who choose home HD.

\section{Disclosure}

RCW is supported by the University of Sydney APA Scholarship, Baxter Clinical Evidence Council research programme, and New Zealand Lotteries Health Research Grant. The other authors report no conflicts of interest in this work.

\section{References}

1. Blagg CR. Home haemodialysis. BMJ. 2008;336(7634):3-4.

2. Blagg CR. Home haemodialysis: 'home, home, sweet, sweet home!'. Nephrology (Carlton). 2005;10(3):206-214.

3. Cass A, Chadban S, Gallagher M, et al. The Economic Impact of Endstage Kidney Disease in Australia: Projections to 2020. Melbourne: Kidney Health Australia; 2010.

4. Kerr M, Bray B, Medcalf J, O’Donoghue DJ, Matthews B. Estimating the financial cost of chronic kidney disease to the NHS in England. Nephrol Dial Transplant. 2012;27 (Suppl 3):iii73- iii80.

5. Liyanage $\mathrm{T}$, Ninomiya $\mathrm{T}$, Jha $\mathrm{V}$, et al. Worldwide access to treatment for end-stage kidney disease: a systematic review. Lancet. 2015;385(9981): 1975-1982.

6. Saran R, Li Y, Robinson B, et al. US Renal Data System 2015 Annual Data Report: epidemiology of kidney disease in the United States. Am J Kidney Dis. 67(3 Suppl 1):S1-S305.

7. Rao A, Casula A, Castledine C. UK Renal Registry 17th Annual Report: Chapter 2 UK renal replacement therapy prevalence in 2013: national and centre-specific analyses. Nephron. 2015;129 (Supp1 1):31-56.

8. National Institute of Care Excellence. Guidance on home compared with hospital haemodialysis for patients with end-stage renal failure; 2002. Available from: http://www.nice.org.uk/nicemedia/ live/11472/32449/32449.pdf. Accessed July 22, 2014.

9. FHN Trial Group, Chertow GM, Levin NW, et al. In-center hemodialysis six times per week versus three times per week. $N$ Engl J Med. 2010;363(24):2287-2300.

10. Culleton BF, Walsh M, Klarenbach SW, et al. Effect of frequent nocturnal hemodialysis vs conventional hemodialysis on left ventricular mass and quality of life: a randomized controlled trial. JAMA. 2007;298(11):1291-1299.

11. Rocco MV, Lockridge RS, Beck GJ, et al. The effects of frequent nocturnal home hemodialysis: the Frequent Hemodialysis Network Nocturnal Trial. Kidney Int. 2011;80(10):1080-1091.

12. Blagg CR, Kjellstrand CM, Ting GO, Young BA. Comparison of survival between short-daily hemodialysis and conventional hemodialysis using the standardized mortality ratio. Hemodial Int. 2006;10(4):371-374.

13. Nesrallah GE, Lindsay RM, Cuerden MS, et al. Intensive hemodialysis associates with improved survival compared with conventional hemodialysis. J Am Soc Nephrol. 2012;23(4):696-705.
14. Marshall MR, Hawley CM, Kerr PG, et al. Home hemodialysis and mortality risk in Australian and New Zealand populations. Am J Kidney Dis. 2011;58(5):782-793.

15. Marshall MR, Walker RC, Polkinghorne KR, Lynn KL. Survival on home dialysis in New Zealand. PLoS One. 2014;9(5):e96847.

16. Morton RL, Tong A, Howard K, Snelling P, Webster AC. The views of patients and carers in treatment decision making for chronic kidney disease: systematic review and thematic synthesis of qualitative studies. BMJ. 2010;340:c112.

17. Suri RS, Larive B, Garg AX, et al. Burden on caregivers as perceived by hemodialysis patients in the Frequent Hemodialysis Network (FHN) trials. Nephrol Dial Transplant. 2011;26(7):2316-2322.

18. Rajkomar A, Farrington K, Mayer A, Walker D, Blandford A. Patients' and carers' experiences of interacting with home haemodialysis technology: implications for quality and safety. BMC Nephrol. 2014;15(1):195.

19. Tong A, Palmer S, Manns B, et al. The beliefs and expectations of patients and caregivers about home haemodialysis: an interview study. BMJ Open. 2013;3(1):pii: e002148.

20. Schlaeper C, Diaz-Buxo JA. Home hemodialysis and remote monitoring: current technology, requirements and capabilities. Blood Purif. 2005;23(1):18-22.

21. Pauly RP, Gill JS, Rose CL, et al. Survival among nocturnal home haemodialysis patients compared to kidney transplant recipients. Nephrol Dial Transplant. 2009;24(9):2915-2919.

22. Walker RC, Hanson CS, Palmer SC, et al. Patient and caregiver perspectives on home hemodialysis: a systematic review. Am J Kidney Dis. 2015;65(3):451-463.

23. Walker RC, Howard K, Morton RL, Palmer SC, Marshall MR, Tong A. Patient and caregiver values, beliefs and experiences when considering home dialysis as a treatment option: a semi-structured interview study. Nephrol Dial Transplant. 2015;31(1):133-141.

24. Walker RC, Howard K, Tong A, Palmer SC, Marshall MR, Morton RL. The economic considerations of patients and caregivers in choice of dialysis modality. Hemodial Int. 2016;20(4):634-642.

25. Morton RL, Devitt J, Howard K, Anderson K, Snelling P, Cass A. Patient views about treatment of stage $5 \mathrm{CKD}$ : a qualitative analysis of semistructured interviews. Am J Kidney Dis. 2010;55(3):431-440.

26. Morton RL, Snelling P, Webster AC, et al. Dialysis modality preference of patients with CKD and family caregivers: a discrete-choice study. Am J Kidney Dis. 2012;60(1):102-111.

27. Morton RL, Snelling P, Webster AC, et al. Factors influencing patient choice of dialysis versus conservative care to treat end-stage kidney disease. CMAJ. 2012;184(5):E277-E283.

28. Tong A, Crowe S, Chando S, et al. Research priorities in CKD: report of a National Workshop conducted in Australia. Am J Kidney Dis. 2015; $66(2) ; 212-222$.

29. Muehrer RJ, Schatell D, Witten B, Gangnon R, Becker BN, Hofmann RM. Factors affecting employment at initiation of dialysis. Clin J Am Soc Nephrol. 2011;6(3):489-496.

30. Hergenrather KC, Zeglin RJ, McGuire-Kuletz M, Rhodes SD. Employment as a social determinant of health: a review of longitudinal studies exploring the relationship between employment status and mental health. Rehab Res Policy Educ. 2015;29(3):261-290.

31. Helanterä I, Haapio M, Koskinen P, Grönhagen-Riska C, Finne P. Employment of patients receiving maintenance dialysis and after kidney transplant: a cross-sectional study from Finland. Am J Kidney Dis. 2012;59(5):700-706.

32. Rosenthal MM, Molzahn AE, Chan CT, Cockfield SL, Kim SJ, Pauly RP. Why take the chance: a qualitative grounded theory study of nocturnal hemodialysis recipients who decline kidney transplantation. BMJOpen. 2016;6:e011951.

33. Hanson CS, Chapman JR, Craig JC, et al. Patient experiences of training and transition to home haemodialysis: a mixed methods study. Nephrology (Carlton). Epub 2016 Jun 2.

34. Young BA, Chan $\mathrm{C}$, Blagg $\mathrm{C}$, et al. How to overcome barriers and establish a successful home HD program. Clin J Am Soc Nephrol. 2012; 7(12):2023-2032. 
35. McLaughlin K, Manns B, Mortis G, Hons R, Taub K. Why patients with ESRD do not select self-care dialysis as a treatment option. Am J Kidney Dis. 2003;41(2):380-385.

36. Mehrotra R, Marsh D, Vonesh E, Peters V, Nissenson A. Patient education and access of ESRD patients to renal replacement therapies beyond in-center hemodialysis. Kidney Int. 2005;68(1):378-390.

37. Walker RC, Blagg CR, Mendelssohn DC. Systems to cultivate suitable patients for home dialysis. Hemodial Int. 2015;19(Suppl 1): S52-S58.

38. Cornelis T, Tennankore KK, Goffin E, et al. An international feasibility study of home haemodialysis in older patients. Nephrol Dial Transplant. 2014;29(2):2327-2333.

39. Pierratos A, Tremblay M, Kandasamy G, et al. Personal Support Worker (PSW)-supported home hemodialysis: a paradigm shift. Hemodial Int. Epub 2016 Aug 22.

40. Marshall MR, van der Schrieck N, Lilley D, et al. Independent community house hemodialysis as a novel dialysis setting: an observational cohort study. Am J Kidney Dis. 2013;61(4):598-607.

41. Ludlow MJ, Lauder LA, Mathew TH, Hawley CM, Fortnum D. Australian consumer perspectives on dialysis: first national census. Nephrology. 2012;17(8):703-709.

42. Howard K, McFarlane PA, Marshall MR, Eastwood DO, Morton RL. Funding and planning: what you need to know for starting or expanding a home hemodialysis program. Hemodial Int. 2015;19(S1): S23-S42.

43. Walker RC, Morton RL, Tong A, Marshall MR, Palmer S, Howard K. Patient and caregiver preferences for home dialysis-the home first study: a protocol for qualitative interviews and discrete choice experiments. BMJ Open. 2015;5(4):e007405.

44. Ludlow MJ, George CR, Hawley CM, et al. How Australian nephrologists view home dialysis: results of a national survey. Nephrology (Carlton). 2011;16(4):446-452.

45. Pauly RP, Komenda P, Chan CT, et al. Programmatic variation in home hemodialysis in Canada: results from a nationwide survey of practice patterns. Can J Kidney Health Dis. 2014;1(1):11.

46. Mowatt G, Vale L, Perez J, et al. Systematic review of the effectiveness and cost-effectiveness, and economic evaluation, of home versus hospital or satellite unit haemodialysis for people with end-stage renal failure. Health Technol Assess. 2003;7(2):1-174.

47. Walker R, Marshall M, Morton RL, McFarlane P, Howard K. The cost effectiveness of contemporary home haemodialysis modalities compared to facility haemodialysis: a systematic review of full economic evaluations. Nephrology. 2014;19(8):459-470.

48. Liu FX, Treharne C, Arici M, Crowe L, Culleton B. High-dose hemodialysis versus conventional in-center hemodialysis: a cost-utility analysis from a UK payer perspective. Value Health. 2015;18(1):17-24.

49. Morton RL, Tong A, Howard K, Snelling P, Webster AC. The views of patients and carers in treatment decision making for chronic kidney disease: systematic review and thematic synthesis of qualitative studies. BMJ. 2010;340:c112.

50. Brill A. Economic Benefits of Increased Home Dialysis Utilization and Innovation; 2016. Available from: http://www.nephrologynews.com/ wp-content/uploads/2016/03/MGAhomedialysispaperforrelease.pdf. Accessed August 25, 2016.
51. Vanholder R, Davenport A, Hannedouche T, et al. Reimbursement of dialysis: a comparison of seven countries. J Am Soc Nephrol. 2012;23(8): 1291-1298.

52. Robinson BM, Akizawa T, Jager KJ, Kerr PG, Saran R, Pisoni RL. Factors affecting outcomes in patients reaching end-stage kidney disease worldwide: differences in access to renal replacement therapy, modality use, and haemodialysis practices. Lancet. 2016;388(10041):294-306.

53. Rivara MB, Mehrotra R. The changing landscape of home dialysis in the United States. Curr Opin Nephrol Hypertens. 2014;23(6):586-591.

54. Combes G, Allen K, Sein K, Girling A, Lilford R. Taking hospital treatments home: a mixed methods case study looking at the barriers and success factors for home dialysis treatment and the influence of a target on uptake rates. Implement Sci. 2015;10(1):148.

55. Teerawattananon Y, Luz A, Pilasant S, et al. How to meet the demand for good quality renal dialysis as part of universal health coverage in resource-limited settings? Health Res Policy Sys. 2016;14(1):21.

56. McDonald SP, Marshall MR, Johnson DW, Polkinghorne KR. Relationship between dialysis modality and mortality. J Am Soc Nephrol. 2009;20(1):155-163.

57. Nadeau-Fredette A-C, Bargman JM, Chan CT. Clinical outcome of home hemodialysis in patients with previous peritoneal dialysis exposure: evaluation of the integrated home dialysis model. Perit Dial Int. 2015;35(3):316-323.

58. Cinà DP, Dacouris N, Kashani M, et al. Use of home hemodialysis after peritoneal dialysis technique failure. Perit Dial Int. 2013;33(1):96-99.

59. Navva PKR, Venkata Sreepada S, Shivanand Nayak K. Present status of renal replacement therapy in Asian countries. Blood Purif. 2015;40(4):280-287.

60. ANZDATA Registry. 37th Report. Preliminary Report. 2014: Summary of Dialysis and Transplant in Australia and New Zealand. Adelaide, Australia: Australia and New Zealand Dialysis and Transplant Registry; 2015. Available from: http://www.anzdata.org.au. Accessed August 25, 2016.

61. New Zealand National Renal Advisory Board. New Zealand Nephrology Activity Report 2014. Wellington, New Zealand: Publisher Ministry of Health; 2016.

62. Avalere Health. Distribution of Dialysis Patients Utilizing Home modalities in 2013 by State. Available from http://homedialysisalliance. org/userfiles/2014\%20edition_Distribution\%20of\%20Dialysis \%20 Patients\%20Utilizing\%20Home\%20Modalities\%20by\%20State\%20 in\%202012.pdf. Accessed August 26, 2016.

63. Morton RL, Schlackow I, Mihaylova B, Staplin ND, Gray A, Cass A. The impact of social disadvantage in moderate-to-severe chronic kidney disease: an equity-focused systematic review. Nephrol Dial Transplant. 2015;31(1):46-56.

64. Berns JS. Honoring patient preferences: the 2016 National Kidney Foundation presidential address. Am J Kidney Dis. 2016;68(5):661-664.

65. Merighi JR, Schatell DR, Bragg-Gresham JL, Witten B, Mehrotra R. Insights into nephrologist training, clinical practice, and dialysis choice. Hemodial Int. 2012;16(2):242-251.

66. Breckenridge K, Bekker HL, Gibbons E, et al. How to routinely collect data on patient-reported outcome and experience measures in renal registries in Europe: an expert consensus meeting. Nephrol Dial Transplant. 2015;30(10):1605-1614. 


\section{Supplementary material}

Table SI Included studies

\begin{tabular}{|c|c|c|c|c|}
\hline Author & Year & Title & Journal & Subtopic \\
\hline Agar et al' & 2005 & $\begin{array}{l}\text { Nocturnal haemodialysis: an Australian cost } \\
\text { comparison with conventional satellite } \\
\text { haemodialysis }\end{array}$ & Nephrology & Economic perspective \\
\hline Barneih et $\mathrm{al}^{2}$ & 2014 & $\begin{array}{l}\text { Views of Canadian patients on or nearing dialysis } \\
\text { and their caregivers: a thematic analysis }\end{array}$ & $\begin{array}{l}\text { Candaian Journal of Kidney Health } \\
\text { and Disease }\end{array}$ & Patient perspective \\
\hline Berns et $\mathrm{al}^{3}$ & 2015 & $\begin{array}{l}\text { Honoring patient preferences: the } 2016 \text { National } \\
\text { Kidney Foundation Presidential Address }\end{array}$ & $A J K D$ & Patient perspective \\
\hline Blogg et $\mathrm{al}^{4}$ & 2008 & $\begin{array}{l}\text { The experience of spouses caring for a person } \\
\text { on home haemodialysis: an ethnography }\end{array}$ & RSAJ & Patient perspective \\
\hline Brill et al ${ }^{5}$ & 2014 & $\begin{array}{l}\text { Economic benefits of increased home dialysis } \\
\text { utilization and innovation }\end{array}$ & Report & Economic perspective \\
\hline Cafazzo et $\mathrm{a}^{6}$ & 2009 & $\begin{array}{l}\text { Patient-perceived barriers to the adoption of } \\
\text { nocturnal home hemodialysis }\end{array}$ & CJASN & Patient perspective \\
\hline Cases et $\mathrm{al}^{7}$ & 2011 & $\begin{array}{l}\text { The experience of individuals with renal failure } \\
\text { participating in home haemodialysis: an } \\
\text { interpretative phenomenological analysis. }\end{array}$ & Journal of Health Psychology & Patient perspective \\
\hline Cass et $\mathrm{al}^{8}$ & 2010 & $\begin{array}{l}\text { The economic impact of end-stage kidney disease } \\
\text { in Australia: projections to } 2020\end{array}$ & Report & Economic perspective \\
\hline Cina et $\mathrm{al}^{9}$ & 2013 & $\begin{array}{l}\text { Use of home hemodialysis after peritoneal dialysis } \\
\text { technique failure }\end{array}$ & PDI & Patient perspective \\
\hline Combes et $\mathrm{al}^{10}$ & 2015 & $\begin{array}{l}\text { Taking hospital treatments home: a mixed } \\
\text { methods case study looking at the barriers and } \\
\text { success factors for home dialysis treatment and } \\
\text { the influence of a target on uptake rates }\end{array}$ & Implementation Science & Patient perspective \\
\hline Cornelis et al" & 2014 & $\begin{array}{l}\text { An international feasibility study of home } \\
\text { haemodialysis in older patients }\end{array}$ & NDT & Patient perspective \\
\hline Courts et al ${ }^{12}$ & 2000 & $\begin{array}{l}\text { Psychosocial adjustment of patients on home } \\
\text { hemodialysis and their dialysis partners }\end{array}$ & Clinical Nursing Research & Patient perspective \\
\hline Giles et $\mathrm{a}^{13}$ & 2003 & $\begin{array}{l}\text { A phenomenological investigation into the life- } \\
\text { world of home haemodialysis }\end{array}$ & Social Work in Health Care & Patient perspective \\
\hline Giles et a $\left.\right|^{14}$ & 2005 & $\begin{array}{l}\text { The paradox of living with a home haemodialysis } \\
\text { machine }\end{array}$ & Social Work in Health Care & Patient perspective \\
\hline Gonzalez-Perez et a $\left.\right|^{15}$ & 2005 & $\begin{array}{l}\text { Hemodialysis for end-stage renal disease: a cost- } \\
\text { effectiveness analysis of treatment-options }\end{array}$ & Int J Technol Assess Health Care & Economic perspective \\
\hline Hanson et al ${ }^{16}$ & 2016 & $\begin{array}{l}\text { Patient experiences of training and transition to } \\
\text { home haemodialysis: a mixed methods study }\end{array}$ & Nephrology & Patient perspective \\
\hline Helentera et a $\left.\right|^{17}$ & 2012 & $\begin{array}{l}\text { Employment of patients receiving maintenance } \\
\text { dialysis and after kidney transplant: a cross- } \\
\text { sectional study from Finland }\end{array}$ & $A J K D$ & Patient perspective \\
\hline Howard et al ${ }^{18}$ & 2009 & $\begin{array}{l}\text { The cost-effectiveness of increasing kidney } \\
\text { transplantation and home-based dialysis }\end{array}$ & Nephrology & Economic perspective \\
\hline Howard et al ${ }^{19}$ & 2015 & $\begin{array}{l}\text { Funding and planning: what you need to know for } \\
\text { starting or expanding a home hemodialysis } \\
\text { program }\end{array}$ & Hemodialysis International & Economic perspective \\
\hline Klarenbach et $\mathrm{a}^{20}$ & 2014 & $\begin{array}{l}\text { Economic evaluation of frequent home nocturnal } \\
\text { hemodialysis based on a randomized controlled } \\
\text { trial }\end{array}$ & JASN & Economic perspective \\
\hline Komenda et $\mathrm{a}^{21}$ & 2012 & $\begin{array}{l}\text { An economic assessment model for in-center, } \\
\text { conventional home, and more frequent home } \\
\text { hemodialysis }\end{array}$ & Kidney International & Economic perspective \\
\hline Komenda et $\mathrm{a}^{22}$ & 2010 & $\begin{array}{l}\text { The cost of starting and maintaining a large home } \\
\text { hemodialysis program }\end{array}$ & Kidney International & Economic perspective \\
\hline Kroeker et $\mathrm{al}^{23}$ & 2003 & $\begin{array}{l}\text { An operating cost comparison between } \\
\text { conventional and home quotidian hemodialysis }\end{array}$ & $A J K D$ & Economic perspective \\
\hline
\end{tabular}

(Continued) 
Table SI (Continued)

\begin{tabular}{|c|c|c|c|c|}
\hline Author & Year & Title & Journal & Subtopic \\
\hline Lim et $\mathrm{al}^{24}$ & 2010 & $\begin{array}{l}\text { How public and private reforms dramatically } \\
\text { improved access to dialysis therapy in Malaysia }\end{array}$ & Health Affairs & Equity perspective \\
\hline Liu et $\mathrm{a}^{25}$ & 2015 & $\begin{array}{l}\text { High-dose hemodialysis versus conventional in- } \\
\text { center hemodialysis: a cost-utility analysis from a } \\
\text { UK payer perspective }\end{array}$ & Value in Health & Economic perspective \\
\hline Liyanage et $\mathrm{al}^{26}$ & 2015 & $\begin{array}{l}\text { Worldwide access to treatment for end-stage } \\
\text { kidney disease: a systematic review }\end{array}$ & The Lancet & Equity perspective \\
\hline Ludlow et $\mathrm{al}^{27}$ & 2012 & $\begin{array}{l}\text { Australian consumer perspectives on dialysis: first } \\
\text { national census }\end{array}$ & Nephrology & Patient perspective \\
\hline Malmstrom et $\mathrm{al}^{28}$ & 2008 & $\begin{array}{l}\text { Cost analysis and health-related quality of life of } \\
\text { home and self-care satellite haemodialysis }\end{array}$ & NDT & $\begin{array}{l}\text { Economic and patient } \\
\text { perspective }\end{array}$ \\
\hline Manns et $\mathrm{al}^{29}$ & 2007 & $\begin{array}{l}\text { The economics of end-stage renal disease care in } \\
\text { Canada: incentives and impact on delivery of care }\end{array}$ & Int J Health Care Finance Econ & Economic perspective \\
\hline Marshall et al ${ }^{30}$ & 2013 & $\begin{array}{l}\text { Independent community house hemodialysis as } \\
\text { a novel dialysis setting: an observational cohort } \\
\text { study }\end{array}$ & $A J K D$ & Patient perspective \\
\hline McFarlane et $\mathrm{al}^{31}$ & 2003 & $\begin{array}{l}\text { The quality of life and cost utility of home } \\
\text { nocturnal and conventional in-center hemodialysis }\end{array}$ & Kidney International & Economic perspective \\
\hline McFarlane et $\mathrm{a}^{32}$ & 2011 & $\begin{array}{l}\text { Economic considerations in frequent home } \\
\text { hemodialysis }\end{array}$ & Seminars in Dialysis & Economic perspective \\
\hline McLaughlin et a $\mathrm{a}^{13}$ & 2003 & $\begin{array}{l}\text { Why patients with ESRD do not select self-care } \\
\text { dialysis as a treatment option }\end{array}$ & $A J K D$ & Patient perspective \\
\hline Mehrotra et $\mathrm{al}^{34}$ & 2005 & $\begin{array}{l}\text { Patient education and access of ESRD patients } \\
\text { to renal replacement therapies beyond in-center } \\
\text { hemodialysis }\end{array}$ & Kidney Int & Patient perspective \\
\hline Mohr et $\mathrm{a}^{35}$ & 2001 & $\begin{array}{l}\text { The case for daily dialysis: its impact on costs and } \\
\text { quality of life }\end{array}$ & $A J K D$ & Economic perspective \\
\hline Morton et $\mathrm{al}^{36}$ & 2010 & $\begin{array}{l}\text { Patient views about treatment of stage } 5 \mathrm{CKD} \text { : a } \\
\text { qualitative analysis of semistructured interviews }\end{array}$ & $A J K D$ & Patient perspective \\
\hline Morton et $\mathrm{a}^{37}$ & 2010 & $\begin{array}{l}\text { The views of patients and carers in treatment } \\
\text { decision making for chronic kidney disease: } \\
\text { systematic review and thematic synthesis of } \\
\text { qualitative studies }\end{array}$ & $B M J$ & Patient perspective \\
\hline Morton et $\mathrm{al}^{38}$ & 2011 & $\begin{array}{l}\text { Characteristics of dialysis important to patients } \\
\text { and family caregivers: a mixed methods approach }\end{array}$ & NDT & Patient perspective \\
\hline Morton et $\mathrm{al}^{39}$ & 2012 & $\begin{array}{l}\text { Dialysis modality preference of patients with CKD } \\
\text { and family caregivers: a discrete-choice study }\end{array}$ & $A J K D$ & Patient perspective \\
\hline Morton et al ${ }^{40}$ & 2015 & $\begin{array}{l}\text { The impact of social disadvantage in moderate-to- } \\
\text { severe chronic kidney disease: an equity-focused } \\
\text { systematic review }\end{array}$ & NDT & Equity perspective \\
\hline Muehrer et $\mathrm{al}^{41}$ & 2011 & $\begin{array}{l}\text { Factors affecting employment at initiation of } \\
\text { dialysis }\end{array}$ & CJASN & Patient perspective \\
\hline Muehrer et $\mathrm{al}^{29}$ & 2011 & $\begin{array}{l}\text { Factors affecting employment at initiation of } \\
\text { dialysis }\end{array}$ & CJASN & Patient perspective \\
\hline Namiki et $\mathrm{al}^{42}$ & 2010 & $\begin{array}{l}\text { Living with home-based haemodialysis: insights } \\
\text { from older people }\end{array}$ & Journal of Clinical Nursing & Patient perspective \\
\hline Navva et $\mathrm{al}^{43}$ & 2015 & $\begin{array}{l}\text { Present status of renal replacement therapy in } \\
\text { Asian countries }\end{array}$ & Blood Purification & Economic perspective \\
\hline Osterlund et $\mathrm{al}^{44}$ & 2014 & $\begin{array}{l}\text { Identification of facilitators and barriers to home } \\
\text { dialysis selectin by Canadian adults with ESRD }\end{array}$ & Seminars in Dialysis & Patient perspective \\
\hline Pierratos et $\mathrm{a}^{45}$ & 2016 & $\begin{array}{l}\text { Personal Support Worker (PSW)-supported } \\
\text { home hemodialysis: a paradigm shift }\end{array}$ & Hemodialysis International & Patient perspective \\
\hline Polaschek et $\mathrm{al}^{46}$ & 2003 & $\begin{array}{l}\text { Living on dialysis: concerns of clients in a renal } \\
\text { setting }\end{array}$ & Journal of Advanced Nursing & Patient perspective \\
\hline Polaschek et $\mathrm{al}^{47}$ & 2003 & $\begin{array}{l}\text { Haemodialysing at home: the client experience of } \\
\text { self-treatment }\end{array}$ & Journal of Renal Care & Patient perspective \\
\hline
\end{tabular}

(Continued) 
Table SI (Continued)

\begin{tabular}{|c|c|c|c|c|}
\hline Author & Year & Title & Journal & Subtopic \\
\hline Rivara et al $^{48}$ & 2014 & $\begin{array}{l}\text { The changing landscape of home dialysis in the } \\
\text { United States }\end{array}$ & $\begin{array}{l}\text { Current Opinion in Nephrology and } \\
\text { Hypertension }\end{array}$ & Economic perspective \\
\hline Robinson et al $^{49}$ & 2016 & $\begin{array}{l}\text { Factors affecting outcomes in patients reaching } \\
\text { end-stage kidney disease worldwide: differences in } \\
\text { access to renal replacement therapy, modality use, } \\
\text { and haemodialysis practices }\end{array}$ & The Lancet & Patient perspective \\
\hline Teerawattananon et $\mathrm{al}^{50}$ & 2015 & $\begin{array}{l}\text { How to meet the demand for good quality renal } \\
\text { dialysis as part of universal health coverage in } \\
\text { resource-limited settings? }\end{array}$ & Health Research Policy and Systems & Economic perspective \\
\hline Tong et $\mathrm{al}^{51}$ & 2013 & $\begin{array}{l}\text { The beliefs and expectations of patients and } \\
\text { caregivers about home haemodialysis: an interview } \\
\text { study }\end{array}$ & BMJ Open & Patient perspective \\
\hline Tong et $\mathrm{al}^{52}$ & 2015 & $\begin{array}{l}\text { Research Priorities in CKD: Report of a National } \\
\text { Workshop Conducted in Australia }\end{array}$ & AJKD & Patient perspective \\
\hline Vanholder et $\mathrm{al}^{53}$ & 2012 & $\begin{array}{l}\text { Reimbursement of dialysis: a comparison of seven } \\
\text { countries }\end{array}$ & Nephrology & Economic perspective \\
\hline Vestman et $\mathrm{al}^{54}$ & 2014 & $\begin{array}{l}\text { Freedom and confinement: Patients' experiences } \\
\text { of life with home haemodialysis }\end{array}$ & Nursing Research and Practice & Patient perspective \\
\hline Walker et $\mathrm{al}^{55}$ & 2015 & $\begin{array}{l}\text { Patient and caregiver perspectives on home } \\
\text { hemodialysis: A systematic review }\end{array}$ & AJKD & Patient perspective \\
\hline Walker et $\mathrm{al}^{56}$ & 2014 & $\begin{array}{l}\text { The cost effectiveness of contemporary home } \\
\text { haemodialysis modalities compared to facility } \\
\text { haemodialysis: A systematic review of full economic } \\
\text { evaluations }\end{array}$ & Nephrology & Economic perspective \\
\hline Walker et al ${ }^{57}$ & 2016 & $\begin{array}{l}\text { The economic considerations of patients and } \\
\text { caregivers in choice of dialysis modality }\end{array}$ & Hemodialysis International & Patient perspective \\
\hline Wong et $\mathrm{al}^{58}$ & 2009 & $\begin{array}{l}\text { Patients' experiences with learning a complex } \\
\text { medical device for the self-administration of } \\
\text { nocturnal home hemodialysis }\end{array}$ & Nephrology Nursing Journal & Patient perspective \\
\hline Wyld et al $^{59}$ & 2012 & $\begin{array}{l}\text { A systematic review and meta-analysis of utility- } \\
\text { based quality of life in chronic kidney disease } \\
\text { treatments }\end{array}$ & Plos One & Patient perspective \\
\hline Xi et al $^{60}$ & 2013 & $\begin{array}{l}\text { Patient experiences and preferences on short daily } \\
\text { and nocturnal home hemodialysis }\end{array}$ & Hemodialysis International & Patient perspective \\
\hline Young et $\mathrm{al}^{61}$ & 2012 & $\begin{array}{l}\text { How to overcome barriers and establish a } \\
\text { successful home HD program }\end{array}$ & Clin J Am Soc Nephrol & Patient perspective \\
\hline
\end{tabular}

\section{References}

1. Agar JW, Knight RJ, Simmonds RE, Boddington JM, Waldron CM, Somerville CA. Nocturnal haemodialysis: An Australian cost comparison with conventional satellite haemodialysis (Review Article). Nephrology 2005;10(6):557-570.

2. Barnieh L, King-Shier K, Hemmelgarn B, Laupacis A, Manns L, Manns B. Views of Canadian patients on or nearing dialysis and their caregivers: a thematic analysis. Can J Kidney Health Dis. 2014;1(1):4

3. Berns JS. Honoring patient preferences: The 2016 National Kidney Foundation Presidential Address. Am J Kidney Dis. 2016.

4. Blogg A, Hyde C. The experience of spouses caring for a person on home haemodialysis: an ethnography. Renal Society of Australasia Journal 2008;4(3):75-80.

5. Brill A. Economic Benefits of Increased Home Dialysis Utilization and Innovation. Available from: http://www.nephrologynews.com/ wp-content/uploads/2016/03/MGAhomedialysispaperforrelease.pdf. Accessed August 25, 2016.

6. Cafazzo JA, Leonard K, Easty AC, Rossos PG, Chan CT. Patientperceived barriers to the adoption of nocturnal home hemodialysis. Clinical Journal of the American Society of Nephrology: CJASN 2009;4(4):784-789.
7. Cases A, Dempster M, Davies M, Gamble G. The experience of individuals with renal failure participating in home haemodialysis: An interpretative phenomenological analysis. J Health Psychol. 2011;16(6): 884-894.

8. Cass A, Chadban S, Gallagher M, et al. The Economic Impact of Endstage Kidney Disease in Australia: Projections to 2020. Melbourne: Kidney Health Australia; 2010.

9. Cinà DP, Dacouris N, Kashani M, et al. Use of home hemodialysis after peritoneal dialysis technique failure. Perit Dial Int. 2013; 33(1):96-99.

10. Combes G, Allen K, Sein K, Girling A, Lilford R. Taking hospital treatments home: a mixed methods case study looking at the barriers and success factors for home dialysis treatment and the influence of a target on uptake rates. Implementation Science 2015;10(1):1.

11. Cornelis T, Tennankore KK, Goffin E, et al. An international feasibility study of home haemodialysis in older patients. Nephrol Dial Transplant. 2014:gfu260.

12. Courts NF. Psychosocial adjustment of patients on home hemodialysis and their dialysis partners. Clin Nurs Res. 2000;9(2):177-190.

13. Giles S. Transformations: a phenomenological investigation into the life-world of home haemodialysis. Soc Work Health Care. 2003; 38(2):29-50. 
14. Giles S. Struggles between the body and machine: the paradox of living with a home haemodialysis machine. Soc Work Health Care. 2005;41(2):19-35.

15. Gonzalez-Perez JG, Vale L, Stearns SC, Wordsworth S. Hemodialysis for end-stage renal disease: A cost-effectiveness analysis of treatment options. Int J Technol Assess Health Care. 2005;21(01):32-39.

16. Hanson CS, Chapman JR, Craig JC, et al. Patient experiences of training and transition to home haemodialysis: a mixed methods study. Nephrology 2016.

17. Helanterä I, Haapio M, Koskinen P, Grönhagen-Riska C, Finne P. Employment of patients receiving maintenance dialysis and after kidney transplant: a cross-sectional study from Finland. Am J Kidney Dis. 2012;59(5):700-706.

18. Howard K, Salkeld G, White S, et al. The cost effectiveness of increasing kidney transplantation and home based dialysis. Nephrology 2009;14(1):123-132.

19. Howard K, McFarlane PA, Marshall MR, Eastwood DO, Morton RL. Funding and planning: What you need to know for starting or expanding a home hemodialysis program. Hemodial Int. 2015;19(S1):S23-S42.

20. Klarenbach S, Tonelli M, Pauly R, et al. Economic evaluation of frequent home nocturnal hemodialysis based on a randomized controlled trial. J Am Soc Nephrol. 2014;25(3):587-594.

21. Komenda P, Gavaghan MB, Garfield SS, Poret AW, Sood MM. An economic assessment model for in-center, conventional home, and more frequent home hemodialysis. Kidney Int. 2012;81(3):307-313.

22. Komenda P, Copland M, Makwana J, Djurdjev O, Sood MM, Levin A. The cost of starting and maintaining a large home hemodialysis program. Kidney Int. 2010;77(11):1039-1045.

23. Kroeker A, Clark WF, Heidenheim AP, et al. An operating cost comparison between conventional and home quotidian hemodialysis. Am J Kidney Dis. 2003;42:49-55.

24. Lim T-O, Goh A, Lim Y-N, Zaher ZMM, Suleiman AB. How public and private reforms dramatically improved access to dialysis therapy in Malaysia. Health Affair. 2010;29(12):2214-2222.

25. Liu FX, Treharne C, Arici M, Crowe L, Culleton B. High-dose hemodialysis versus conventional in-center hemodialysis: a cost-utility analysis from a UK payer perspective. Value Health. 2015;18(1):17-24.

26. Liyanage T, Ninomiya $\mathrm{T}$, Jha V, et al. Worldwide access to treatment for end-stage kidney disease: a systematic review. Lancet. 2015;385(9981): 1975-1982.

27. Ludlow MJ, Lauder LA, Mathew TH, Hawley CM, Fortnum D. Australian consumer perspectives on dialysis: first national census. Nephrology 2012;17(8):703-709.

28. Malmström RK, Roine RP, Heikkilä A, et al. Cost analysis and healthrelated quality of life of home and self-care satellite haemodialysis. Nephrol Dial Transplant. 2008;23(6):1990-1996.

29. Manns BJ, Mendelssohn DC, Taub KJ. The economics of end-stage renal disease care in Canada: incentives and impact on delivery of care. Int $J$ Health Care Finance Econ. 2007;7(2-3):149-169.

30. Marshall MR, van der Schrieck N, Lilley D, et al. Independent community house hemodialysis as a novel dialysis setting: an observational cohort study. Am J Kidney Dis. 2013;61(4):598-607.

31. Mcfarlane PA, Bayoumi AM, Pierratos A, Redelmeier DA. The quality of life and cost utility of home nocturnal and conventional in-center hemodialysis. Kidney Int. 2003;64(3):1004-1011.

32. McFarlane P, Komenda P. Economic considerations in frequent home hemodialysis. In: Seminars in Dialysis, Wiley Online Library; 2011: 678-683.

33. McLaughlin K, Manns B, Mortis G, Hons R, Taub K. Why patients with ESRD do not select self-care dialysis as a treatment option. Am J Kidney Dis. 2003;41(2):380-385.

34. Mehrotra R, Marsh D, Vonesh E, Peters V, Nissenson A. Patient education and access of ESRD patients to renal replacement therapies beyond in-center hemodialysis. Kidney Int. 2005;68(1):378-390.

35. Mohr PE, Neumann PJ, Franco SJ, Marainen J, Lockridge R, Ting G. The case for daily dialysis: its impact on costs and quality of life. Am J Kidney Dis. 2001;37(4):777-789.
36. Morton RL, Devitt J, Howard K, Anderson K, Snelling P, Cass A. Patient views about treatment of stage $5 \mathrm{CKD}$ : a qualitative analysis of semistructured interviews. Am J Kidney Dis. 2010;55(3):431-440.

37. Morton RL, Tong A, Howard K, Snelling P, Webster AC. The views of patients and carers in treatment decision making for chronic kidney disease: systematic review and thematic synthesis of qualitative studies. Brit Med J. 2010;340.

38. Morton RL, Tong A, Webster AC, Snelling P, Howard K. Characteristics of dialysis important to patients and family caregivers: a mixed methods approach. Nephrol Dial Transplant. 2011;26(12):4038-4046.

39. Morton RL, Snelling P, Webster AC, et al. Dialysis modality preference of patients with CKD and family caregivers: a discrete-choice study. Am J Kidney Dis. 2012;60(1):102-111.

40. Morton RL, Schlackow I, Mihaylova B, Staplin ND, Gray A, Cass A. The impact of social disadvantage in moderate-to-severe chronic kidney disease: an equity-focused systematic review. Nephrol Dial Transplant. 2015.

41. Muehrer RJ, Schatell D, Witten B, Gangnon R, Becker BN, Hofmann RM. Factors affecting employment at initiation of dialysis. Clin J Am Soc Nephrol. 2011;6(3):489-496.

42. Namiki S, Rowe J, Cooke M. Living with home-based haemodialysis: Insights from older people. J Clin Nurs. 2010;19(3-4):547-555.

43. Navva PKR, Venkata Sreepada S, Shivanand Nayak K. Present status of renal replacement therapy in Asian countries. Blood Purif. 2015;40(4):280-287.

44. Osterlund K, Mendelssohn D, Clase C, Guyatt G, Nesrallah G. Identification of facilitators and barriers to home dialysis selection by Canadian adults with ESRD. In: Seminars in Dialysis, Wiley Online Library; 2014:160-172.

45. Pierratos A, Tremblay M, Kandasamy G, et al. Personal Support Worker (PSW) supported home hemodialysis: a paradigm shift. Hemodial Int. 2016.

46. Polaschek N. Living on dialysis: concerns of clients in a renal setting. JAdv Nurs. 2003;41(1):44-52.

47. Polaschek N. Haemodialysing at home: the client experience of selftreatment. EDTNA/ERCA J. 2005;31(1):27-30.

48. Rivara MB, Mehrotra R. The changing landscape of home dialysis in the United States. Curr Opin Nephrol Hypertens. 2014;23(6):586-591.

49. Robinson BM, Akizawa T, Jager KJ, Kerr PG, Saran R, Pisoni RL. Factors affecting outcomes in patients reaching end-stage kidney disease worldwide: differences in access to renal replacement therapy, modality use, and haemodialysis practices. Lancet 2016.

50. Teerawattananon Y, Luz A, Pilasant S, et al. How to meet the demand for good quality renal dialysis as part of universal health coverage in resource-limited settings? Health Res Policy Syst. 2016;14(1):1.

51. Tong A, Palmer S, Manns B, et al. The beliefs and expectations of patients and caregivers about home haemodialysis: an interview study. BMJ Open 2013;3(1).

52. Tong A, Crowe S, Chando S, et al. Research Priorities in CKD: Report of a National Workshop Conducted in Australia. Am J Kidney Dis. 2015.

53. Vanholder R, Davenport A, Hannedouche T, et al. Reimbursement of dialysis: a comparison of seven countries. J Am Soc Nephrol. 2012;23(8):1291-1298.

54. Vestman C, Hasselroth M, Berglund M. Freedom and confinement: patients' experiences of life with home haemodialysis. Nurs Res Pract. 2014;2014.

55. Walker RC, Howard K, Morton RL, Palmer SC, Marshall MR, Tong A. Patient and caregiver values, beliefs and experiences when considering home dialysis as a treatment option: a semi-structured interview study. Nephrol Dial Transplant. 2015:gfv330.

56. Walker R, Marshall M, Morton RL, McFarlane P, Howard K. The cost effectiveness of contemporary home haemodialysis modalities compared to facility haemodialysis: A systematic review of full economic evaluations. Nephrology 2014;19(8):459-470.

57. Walker RC, Howard K, Tong A, Palmer SC, Marshall MR, Morton RL. The economic considerations of patients and caregivers in choice of dialysis modality. Hemodial Int. 2016. 
58. Wong J, Eakin J, Migram P, Cafazzo JA, Halifax NVD, Chan CT. Patients' experiences with learning a complex medical device for the self-administration of nocturnal home hemodialysis. Nephrol Nurs J. 2009;36(1):27-33.

59. Wyld M, Morton RL, Hayen A, Howard K, Webster AC. A systematic review and meta-analysis of utility-based quality of life in chronic kidney disease treatments. PLoS Med. 2012;9(9):e1001307.
60. Xi W, Singh PM, Harwood L, et al. Patient experiences and preferences on short daily and nocturnal home hemodialysis. Hemodial Int 2013;17(2):201-207.

61. Young BA, Chan C, Blagg C, et al. How to overcome barriers and establish a successful home HD program. Clin J Am Soc Nephrol. 2012;7(12):2023-2032.

\section{Publish your work in this journal}

ClinicoEconomics and Outcomes Research is an international, peerreviewed open-access journal focusing on health technology assessment, pharmacoeconomics and outcomes research in the areas of intervention. The economic impact of health policy and health systems diagnosis, medical devices, and clinical, surgical and pharmacological

Submit your manuscript here: https://www.dovepress.com/clinicoeconomics-and-outcomes-research-journal

organization also constitute important areas of coverage. The manuscript management system is completely online and includes a very quick and fair peer-review system, which is all easy to use. Visit http://www.dovepress.com/testimonials.php to read real quotes from published authors. 